\title{
Temporal variation of microbial population in acclimation and start- up period of a thermophilic desulfurization biofilter
}

\author{
Jingying Zhang, Lin Li, Junxin Liu*, Yunping Han \\ Research Center for Eco-Environmental Sciences, Chinese Academy of Sciences, Beijing 100085, China
}

\section{A R T I C L E I N F O}

\section{Article history:}

Received 22 April 2015

Received in revised form

27 January 2016

Accepted 28 January 2016

Available online 6 February 2016

\section{Keywords:}

Thermophilic biofilter

$\mathrm{SO}_{2}$

Desulfurization bacteria

Acclimatization

Start-up period

DGGE analysis

\begin{abstract}
A B S T R A C T
Microorganisms in a biofilter play important roles in the gas contaminants treatment process. In this study, thermophilic desulfurization bacteria were inoculated in a thermophilic biofilter for $\mathrm{SO}_{2}$ treatment after acclimation and enrichment. Molecular biology techniques were applied to detect temporal variation of microbial population during acclimation and biofilter start-up period. The acclimation temperatures were 50,55 , and $60{ }^{\circ} \mathrm{C}$. Desulfurization bacteria dominated the enrichments. During acclimation, desulfurization bacteria and thermophilic bacteria increased from $36.84 \%$ to $78.95 \%-52.94 \%$ and $88.24 \%$, respectively. In addition, the microbial diversity indices of these enrichments decreased with time. Substrate species and acclimation temperature influenced the microbial structure of the enrichments. The thermophilic biofilter inoculated with enrichments could achieve a rapid start-up, and over $80 \%$ of removal efficiency could be obtained within two weeks. The maximum elimination capacity was $38.71 \mathrm{~g} \mathrm{~m}^{-3} \mathrm{~h}^{-1}$ at $152 \mathrm{mg} \mathrm{m}^{-3}$ inlet concentration. The total sulfur bacteria proportion increased obviously during the start-up period. Moreover, desulfurization bacteria that originally existed in inocula, e.g., Pseudomonas putida, Bacillus thioparans, Microbacterium sp., and Thermoanaerobacteriaceae, were abundant in the thermophilic biofilter for $\mathrm{SO}_{2}$ removal.
\end{abstract}

(C) 2016 Elsevier Ltd. All rights reserved.

\section{Introduction}

Off-gas generated from most industrial and agricultural processes threatens human and ecological health and causes environmental pollution, such as odor nuisance, health effects, crop damage, smog formation, and global warming (Devinny et al., 1999; van Groenestijn and Hesselink, 1993).

Compared with physical (adsorption, absorption, and condensation) and chemical (catalytic combustion, scrubbing, and oxidation) methods, biotechnology provides a more economical and sustainable approach owing to its low operational costs, high removal efficiency, and lack of secondary pollutant generation ( $\mathrm{Li}$ and Liu, 2006; Ralebitso-Senior et al., 2012). For most applications, biological air treatment systems have traditionally relied on microorganisms, generally bacteria, found under ambient environmental conditions (Devinny et al., 1999). An integrated bioreactor with two sections, a suspended aerobic zone (SZ) and immobilized aerobic zone (IZ), was applied to treat $\mathrm{SO}_{2}$ for six

\footnotetext{
* Corresponding author.

E-mail addresses: zhangjingying123@126.com (J. Zhang), leel@rcees.ac.cn (L. Li), jxliu@rcees.ac.cn (J. Liu), yphan@rcees.ac.cn (Y. Han).
}

months. Microbial analysis indicated that $\mathrm{SO}_{2}$ was degraded by Paenibacillus sp. in the IZ, and by Paenibacillus sp. and Ralstonia sp. in the SZ (Lin et al., 2015). Reactor stability and efficacy are maintained by functionally, compositionally, and spatiotemporally dynamic and diverse communities (Xue et al., 2013). Various factors affect the growth kinetics of participating microorganisms, including substrate concentration, moisture content, temperature, electron acceptor, $\mathrm{pH}$, toxic intermediates, and availability of mineral nutrients. Any or a combination of these factors can limit biomass growth rate and substrate biodegradation (Beuger and Gostomski, 2009; Ottengraf, 1986; Sakuma et al., 2008).

Three important time-dependent conditions generally exist for biofilters: start-up response, response to varying loads, and longterm performance. "Start-up" time is the acclimation time required to establish an optimal biological removal. Depending on ambient and site conditions, this start-up procedure may last for weeks or months (Devinny et al., 1999). The start-up period depends on the amount of initial microbial population that can degrade the pollutants; thus, inoculation from an adapted population is desirable (Shareefdeen and Singh, 2005). As an inoculum source, sewage/activated sludge can be trickled over or inoculated directly into a support medium. Alternatively, inocula can be 
cultured in feed reactors to specific biomass concentrations before introducing waste gas. A six times-faster biofiltration start-up of volatile organic solvents can be achieved through inoculation with adapted microorganisms (Saake and Hübner, 1989). Wright et al. found that acclimation in compost biofilters is faster in treating gasoline vapors when the biofilters are inoculated with culture grown on gasoline (Wright et al., 1997). Leson and Smith reached a similar conclusion, suggesting that inoculation hastens acclimation but does not affect the ultimate removal efficiency (Leson and Smith, 1997).

However, few studies have focused on the characteristics of microbial population during acclimatization and bioreactor startup period. $\mathrm{SO}_{2}$, generated from the thermal conversion processing of fuels in power plants, refineries, coal- and oil-fired boilers, and paper pulp production, is harmful to the environment and the human health (Philip and Deshusses, 2003). Therefore, $\mathrm{SO}_{2}$ was used as a target compound in the present study. Desulfurization bacteria were acclimated and enriched to inoculate a thermophilic biofilter to treat $\mathrm{SO}_{2}$. The temporal variations of microbial population during acclimatization and biofilter start-up period were analyzed via polymerase chain reaction-denaturing gradient gel electrophoresis (PCR-DGGE), and fluorescence in situ hybridization (FISH) was applied to describe the microbial population distribution. Biofilter performance was also investigated after desulfurization bacteria inoculation. The aim of this present study is to provide data for rapid start-up and steady operation of the bioreactor, especially for the thermophilic biofilter.

\section{Materials and methods}

\subsection{Acclimation method}

Inoculum samples were collected from a bioreactor that contained $\mathrm{SO}_{2}$ with three packing layers for off-gas treatment. From the bottom to the top layer, the operation temperatures were 60,55 , and $50{ }^{\circ} \mathrm{C}$. The packing samples were obtained from each layer. The detail information of samples was described in Table 1. After transporting to the laboratory, the packing mediums were soaked in Luria-Bertani (LB) medium (BR, Aoboxing Biotech, Co., China). The mediums were then shaken for $1 \mathrm{~h}$ using ultrasonic oscillators (KQ-250B, Kunshan, China). The liquids with suspended cells were cultured in the same nutrient solution in incubator shakers (HZ$9211 \mathrm{~K}$, Taicang, China) at 50,55 , and $60^{\circ} \mathrm{C}$, and at $120 \mathrm{rpm}$ to enrich the microorganisms.

Sulfur bacteria culture media (SCM) was used to enrich and acclimate the three inocula contained in the following components at the specified concentrations (in $\mathrm{g} \mathrm{L}^{-1}$ ): $5.00 \mathrm{Na}_{2} \mathrm{~S}_{2} \mathrm{O}_{3} \cdot 5 \mathrm{H}_{2} \mathrm{O} ; 1.00$ $\mathrm{NaHCO}_{3} ; 2.00 \quad \mathrm{~K}_{2} \mathrm{HPO}_{4} ; 2.00 \quad \mathrm{KNO}_{3} ; 0.01 \quad \mathrm{FeCl}_{2} \cdot 4 \mathrm{H}_{2} \mathrm{O} ; 0.10$
$\mathrm{MgCl}_{4} \cdot 6 \mathrm{H}_{2} \mathrm{O} ; 0.50 \mathrm{NH}_{4} \mathrm{Cl}$; and 5.00 beef extract. Given that $\mathrm{S}^{2-}$ was converted into $\mathrm{H}_{2} \mathrm{~S}$ and was lost as gas from aerobic enrichment, $\mathrm{Na}_{2} \mathrm{~S}_{2} \mathrm{O}_{3}$ was used instead of $\mathrm{Na}_{2} \mathrm{~S}$ as the sulfur substance. The initial $\mathrm{pH}$ of the media was adjusted to 6.5-7.0. Agar (2\%) was added as a solidifying agent. The inocula were replaced monthly with fresh media at a ratio of 10:1 and were sampled regularly to analyze the microbiological indicator.

\subsection{Bioreactor setup}

After the inocula were enriched at 50,55 , and $60{ }^{\circ} \mathrm{C}$ for 12 months, the inocula were mixed at a ratio of $1: 1: 1$ to inoculate into a thermophilic biofiltration (Fig. 1). The biofiltration was a stainless column with a height of $30 \mathrm{~cm}$ and a diameter of $10 \mathrm{~cm}$. The packing material was polyurethane foam cube with an average size of $1.0 \mathrm{~cm}^{3}$. A high-pressure cylinder continuously supplied $\mathrm{SO}_{2}$ to the biofiltration from the air inlet at the bottom of the column. A calibrated mass flow meter was used to control the gas flow rate, and a temperature-controlled oven was supplied to heat the $\mathrm{SO}_{2}$ inlet. The total flow rate was $0.6 \mathrm{~m}^{3} \mathrm{~h}^{-1}$, and the column was maintained at $60{ }^{\circ} \mathrm{C}$ through a thermostat-controlled heating belt. After inoculation, the $\mathrm{SO}_{2}$ concentrations of the inlet and outlet were monitored online using a flue gas analyzer (rbr, Ecom-J2KN, Germany) to determine the removal efficiency. The performance of the bioreactor was evaluated by series parameters, which were defined as follows (formulas 1 and 2):

$$
\begin{aligned}
& R=\left(C_{\text {in }}-C_{\text {out }}\right) \times 100 / C_{\text {in }} \\
& E C=Q \times\left(C_{\text {in }}-C_{\text {out }}\right) / V
\end{aligned}
$$

where $R$ is the removal efficiency (\%), $C_{\text {in }}$ is the inlet concentration of $\mathrm{SO}_{2}\left(\mathrm{mg} \mathrm{m}^{-3}\right), C_{\text {out }}$ is the outlet concentration of $\mathrm{SO}_{2}\left(\mathrm{mg} \mathrm{m}^{-3}\right)$, $E C$ is the elimination capacity $\left(\mathrm{g} \mathrm{m}^{-3} \mathrm{~h}^{-1}\right), Q$ is the flow rate $\left(\mathrm{m}^{3} \mathrm{~h}^{-1}\right)$, and $V$ is the volume of biofilter $\left(\mathrm{m}^{3}\right)$.

\subsection{Microbiological analysis}

Bacteria were incubated in agar-containing LB medium (BR, Aoboxing Biotech, Co., China) at $60^{\circ} \mathrm{C}$ for $24 \mathrm{~h}$. Sulfur bacteria were cultivated in SCM medium at $60^{\circ} \mathrm{C}$ for $3 \mathrm{~d}$. The culture plates were placed in a biochemical incubator (SPX-70BIII, AISITE, Tianjin, China) for thermostatic incubation, and the amount of cells was counted and reported as colony-forming units (CFUs/ml).

\subsubsection{DNA preparation and $16 S$ rRNA gene amplification}

The total DNA extraction was performed by Activated Sludge DNA Automatic Plate form for Magnetic System-16 (TanBead,

Table 1

\begin{tabular}{|c|c|c|c|c|}
\hline \multirow[t]{2}{*}{ No. } & \multirow[t]{2}{*}{ Consortium description } & \multicolumn{2}{|l|}{ Time } & \multirow[t]{2}{*}{ Culture temperature $\left({ }^{\circ} \mathrm{C}\right)$} \\
\hline & & Incubation & Thermophilic biofilter operation & \\
\hline IO-50 & Inoculum & - & - & 50 \\
\hline IO-55 & Inoculum & - & - & 55 \\
\hline IO-60 & Inoculum & - & - & 60 \\
\hline DO-50 & Enrichment & 6 months & - & 50 \\
\hline DO-55 & Enrichment & 6 months & - & 55 \\
\hline DO-60 & Enrichment & 6 months & - & 60 \\
\hline DT-50 & Enrichment & 12 months & - & 50 \\
\hline DT-55 & Enrichment & 12 months & - & 55 \\
\hline DT-60 & Enrichment & 12 months & - & 60 \\
\hline $\mathrm{T}-1$ & Consortium from thermophilic biofilter & - & 1 day & 60 \\
\hline $\mathrm{T}-2$ & Consortium from thermophilic biofilter & - & 11 days & 60 \\
\hline
\end{tabular}

Samples information.

IO: Inoculum; DO: Consortium after 6 months of enrichment; DT: Consortium after 12 months of enrichment; T: Consortium collected from thermophilic biofilter. 


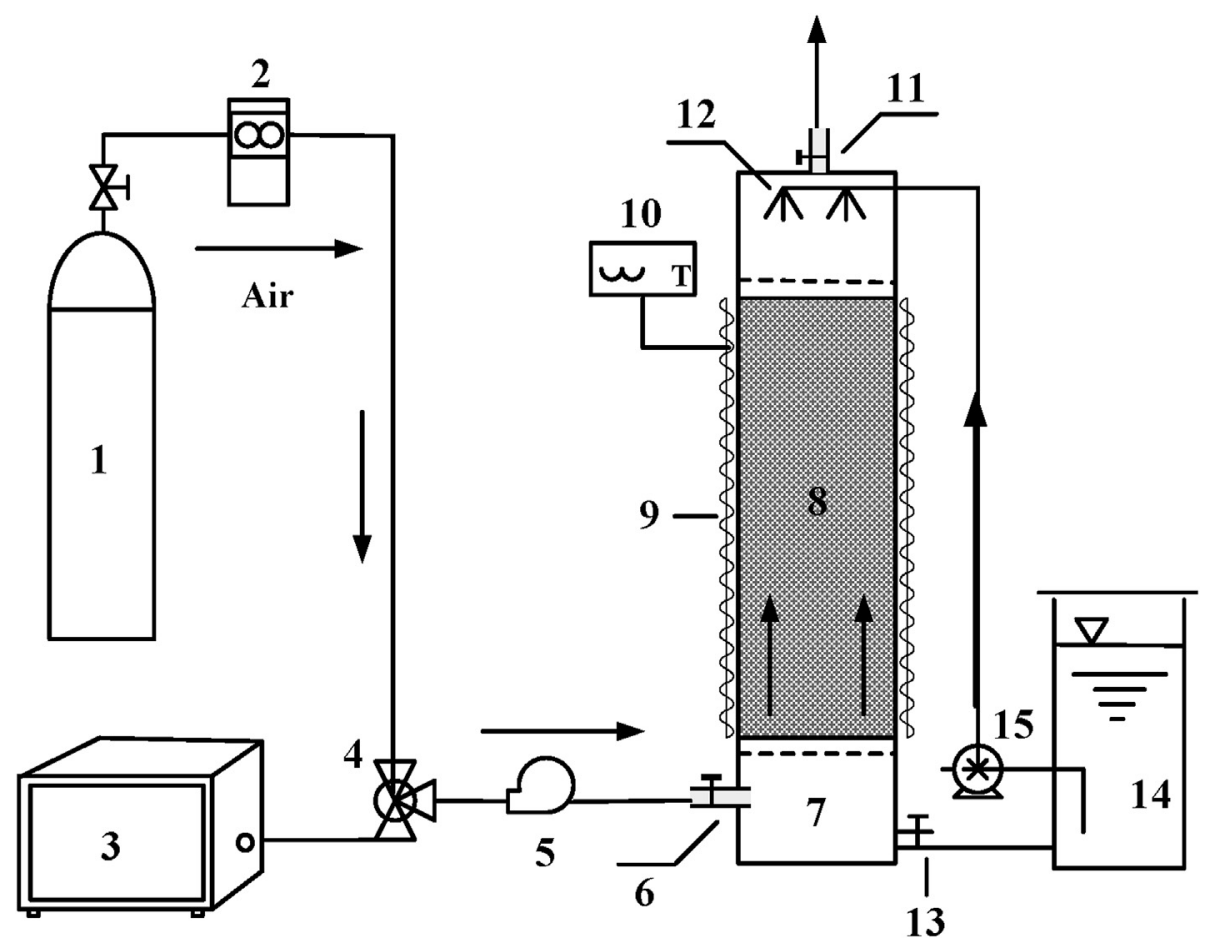

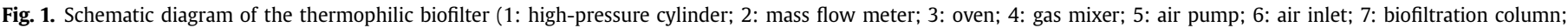
8:packing layer; 9: heating belt; 10: thermostat; 11: air outlet; 12: sprinkler; 13: water outlet; 14: circulating pool; and 15: water pump).

Taiwan), and the DNA bands were determined via 1.0\% agarose gel electrophoresis (Bio-Rad, USA). The V3 regions of the bacterial 16S ribosomal RNA gene of the microbial samples collected from the thermophilic biofilter were amplified directly through polymerase chain reaction (PCR) using a C1000TM Thermal Cycler (Bio-Rad, USA) with specific universal primers F357 (5'-CCTACGGGAGGCAGCAG-3') and R517 (5'-ATTACCGCGGCTGCTGG-3') with the forward primer F357 attached a GC clamp (5'CGCCCGCCGCGCGCGGCGGGCGGGGCGGGGGCACGGGGG-3'). Each $50 \mu \mathrm{L}$ reaction volume contained $5 \mu \mathrm{L}$ extracted DNA, $1 \mu \mathrm{L}$ of each of primer $(10 \mu \mathrm{M}), 4 \mu \mathrm{L}$ of dNTP, $5 \mu \mathrm{L} 10 \times$ Ex Taq buffer $\left(\mathrm{Mg}^{2+}\right.$ Plus $)$, and $1.5 \mathrm{U}$ ExTaq-polymerase (TaKaRa, Dalian, China). The temperature cycling conditions were $94^{\circ} \mathrm{C}$ for $5 \mathrm{~min}$, followed by 30 cycles of $94{ }^{\circ} \mathrm{C}$ for $1 \mathrm{~min}, 48{ }^{\circ} \mathrm{C}$ for $1 \mathrm{~min}$, and $72{ }^{\circ} \mathrm{C}$ for $1 \mathrm{~min}$. A final extension at $72{ }^{\circ} \mathrm{C}$ for $10 \mathrm{~min}$ was also used.

\subsubsection{Denaturing gradient gel electrophoresis-16S rRNA gene analysis}

Denaturing gradient gel electrophoresis (DGGE) was performed on $8 \%(\mathrm{~W} / \mathrm{V})$ polyacrylamide gel with $40 \%-60 \%$ denaturing gradient of denaturants. Electrophoresis was performed in $1 \times$ TAE (TrisAcetate-EDTA) buffer at $60^{\circ} \mathrm{C}$ at a constant voltage of $65 \mathrm{~V}$ for $16 \mathrm{~h}$ using a Bio-Rad DCode system (DCode, Bio-Rad, USA). The gels were stained with SYBR Green I. Digital images were captured using a Fluor-S Multilmager (Gel Doc XR, Bio-Rad, USA) and were analyzed using Quantity One Software (Bio-Rad, USA).

The prominent DGGE bands were excised and dissolved in $35 \mu \mathrm{L}$ of Milli-Q water overnight at $4{ }^{\circ} \mathrm{C}$. The target DNA fragments were reamplified through PCR using the primer set F357/R517 without the GC clamp. The PCR products were ligated into the pEASY-T5 vector and transformed into Escherichia coli TOP10 competent cells (Tiangen, Beijing, China). The clones were cultured on LB agar plates that contained X-gal $(80 \mu \mathrm{g} / \mathrm{ml})$, isopropyl-beta-D-thiogalactopyranoside $(0.5 \mathrm{mM})$, and ampicillin (100 ug/ml). Positive colonies were sequenced using a 3730xL DNA analyzer (ABI, USA).

\subsubsection{Phylogenetic analysis}

Bacterial diversity was determined according to the intensity and number of bands using the Shannon index $(H)$, as previously described (Li et al., 2011). Furthermore, 16S rRNA gene sequences from DGGE bands were analyzed using the Nucleotide-Nucleotide BLAST (Blastn) database (http://www.ncbi.nlm.nih.gov/BLAST) and the Seqmatch program and chimera check program of the Ribosomal Database Project (http://rdp.cme.msu.edu/). The sequences and the closest matches of these sequences retrieved from the database were aligned using the software Clustal $\mathrm{X}$ version 1.8 (Thompson et al., 1997). Phylogenetic trees were constructed using the neighbor-joining method with the software MEGA 6.1. Evolutionary distances of nucleotide sequences were calculated with Kimura 2-parameter model; bootstrap values were obtained with 1000 resamplings.

\subsubsection{Fluorescence in situ hybridization}

The FISH technique was used to assay the functional microbiota distribution in the consortium of microorganisms after acclimation. For the FISH experiments, leachate consortium that contained microorganisms and products were fixed with $4 \%$ paraformaldehyde at $4{ }^{\circ} \mathrm{C}$ for $12 \mathrm{~h}$. The fixed consortium was washed thrice with phosphate-buffered saline ( $\mathrm{pH}: 7.2$ ), and then suspended in the same saline. Moreover, $10 \mu \mathrm{L}$ suspension including microorganisms was spotted as a layer on gelatin-coated glass slides. The air-dried consortium were consecutively dehydrated in $50 \%, 80 \%$, and $100 \%$ ethanol. A hybridization solution that contained $5 \mathrm{ng} \mu \mathrm{L}^{-1}$ of probe was applied to the slide. The FISH procedure was similar to that described by Han (Han et al., 2012). The biomass on the slide was stained with DAPI solution. The FISH images were captured using confocal laser scanning microscopy and were analyzed using the LAS AF Lit software. Table 2 shows the list of the oligonucleotide probes applied and the respective target bacteria. The distribution and relative contents of Pseudomonas sp. and sulfur bacteria in the consortium were detected and analyzed. 
Table 2

List of 16S rRNA gene-targeted oligonucleotide probes used (Saha et al., 2012; Zhao et al., 2009).

\begin{tabular}{|c|c|c|c|c|}
\hline Probes & Fluorescent label & Sequence $\left(5^{\prime}-3^{\prime}\right)$ & $\mathrm{FA}(\%)$ & Specificity \\
\hline Pseudo120 & FITC & ACTACCAGGCAGATTCCTAGGCA & 30 & rRNA group I Pseudomonads \\
\hline Thi-d & TR & TGCTGGTACCGTCATTAGCACACGATG & 35 & Thiobacillus denitrificans \\
\hline
\end{tabular}

FA: Formamide concentration.

\section{Results and discussion}

\subsection{Microbial population of inocula and enrichments}

DGGE analysis of the microorganism revealed community composition distinction from the initial biofilm inocula collected from different parts of the bioreactor (Fig. 2a). A total of 39 discriminable bands (B1 to B39) were identified, and the sequences of these bands were matched with the closest relatives of the bands in the GenBank database, as listed in Table 3. The phylogenetic tree derived from neighbor-joining analysis of the partial 16S rRNA gene sequence is shown in Fig. 3.

\subsubsection{Inocula}

For inocula, lanes IO-50, IO-55, and IO-60 in Fig. 2a represented

a $10-50$ IC-50 DO-50 DT-50 IO-55 IC-55 DO-55 DT-55 IO-60 IC-60 DO-60 DT-60 T-1 T-2
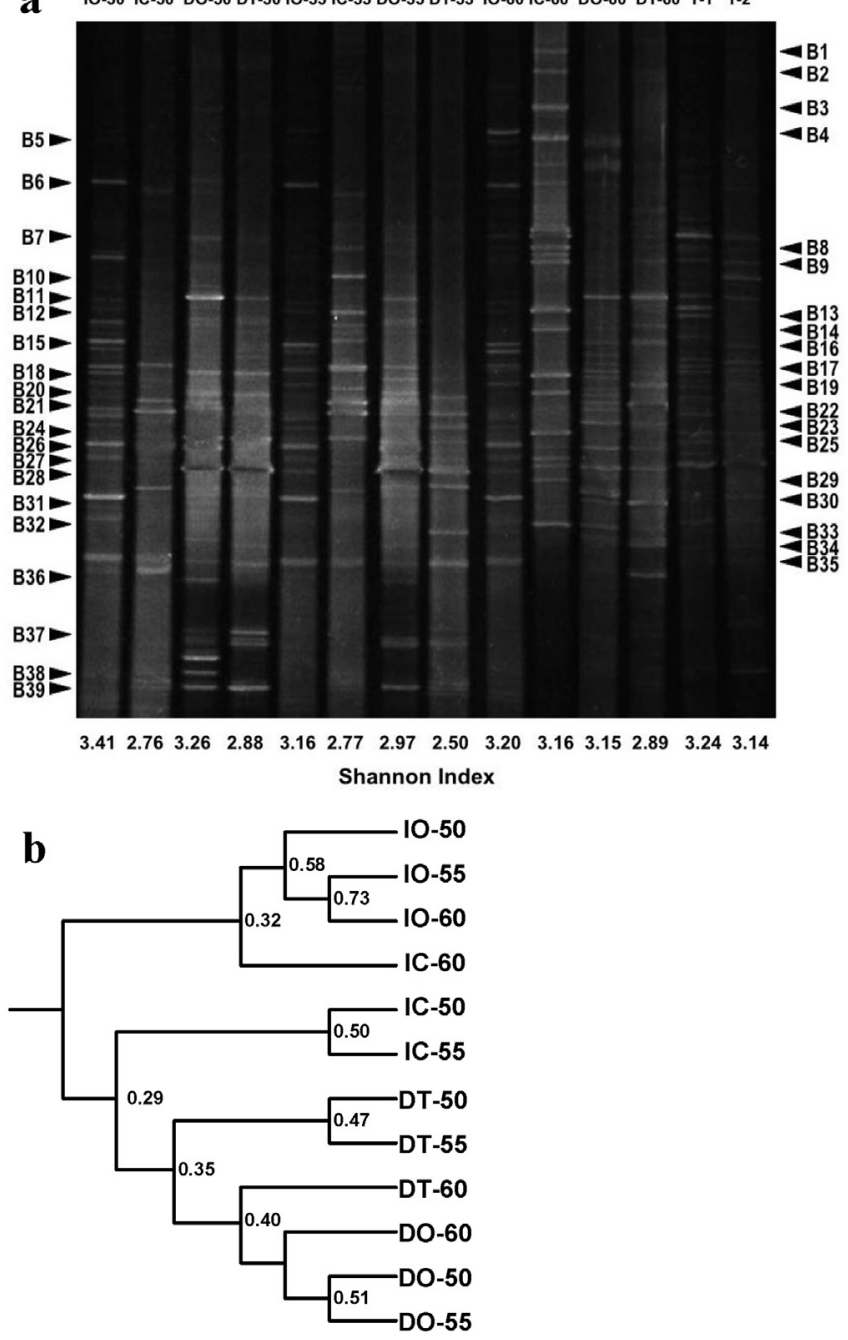

Fig. 2. (a) DGGE profile and Shannon indices of bacterial community, and (b) dendrogram of similarity for the bacteria. the inocula at 50,55 , and $60^{\circ} \mathrm{C}$, respectively. Among these inocula, 18 bands existed under $50{ }^{\circ} \mathrm{C}, 16$ bands at $55^{\circ} \mathrm{C}$, and 16 bands at $60{ }^{\circ} \mathrm{C}$. Seven kinds of bacteria coexisted in the three inocula with different cultured temperatures (IO-50, IO-55, IO-60). Band 26 was closely associated with Bacillus thioparans (100\%), which grew chemolithoautotrophically through oxidation of thiosulfate to sulfate (Pérez-Ibarra et al., 2007). Band 27 and 32 were assigned to Microbacterium sp. (100\%), which was a DMS degrader, and the characteristics of the isolated strain for DMS degradation under batch and continuous conditions were determined (Kayser et al., 2002). A bioreactor inoculated with Microbacterium sp. and Pseudomonas putida can indeed improve the removal of high DMS concentrations (Shu and Chen, 2009). Band 35 and 38 were related to Tuberibacillus calidus (100\%), which was a novel aerobic thermophilic Bacillus, and was isolated from the microbial community in a biofilter for hydrogen sulfide and methanol removal (Hatayama et al., 2006). Band 30 was affiliated with Thermoanaerobacteriaceae (100\%), which was isolated from thermal volcanic spring, hot spring, and high-temperature leachate, and was found with the unique capability of reducing thiosulfate to elemental sulfur in acidic solutions (Shang et al., 2013; Ueno and Tatara, 2008). These four isolates were related to the desulfurization. Band 23 was identified as Aeribacillus pallidus (100\%), which was a thermophilic bacteria usually isolated from hot spring- or crude oilcontaminated soil and was used as bioemulsifier or aromaticdegrading bacterium (Mnif et al., 2014; Yasawong et al., 2011). Band11and 28 had 98\% similarity with uncultured Firmicutes bacterium, and was isolated from a mesophilic digester; it could also be found in microaerobic reactors for biogas desulfurization (Johnson et al., 2008). Band12 and 17 were associated with Anoxybacillus flavithermus (100\%), which could produce thermostable $\alpha$-amylase, and exhibited a unique and remarkable ability to tolerate high toluene, benzene, and p-xyleneon concentrations (Ozdemir et al., 2012). These seven kinds of bacteria were all thermophilic microorganisms.

Band 10, 20, 22, and 25 were detected from IO-50 and IO-55, but not from IO-60. Band 10, 22, and 25 had 100\% similarity with Geobacillus toebii, which was a thermophilic hydrocarbondegrading, heavy metal-resistant bacterium (Kim et al., 2014). Band 20 was associated with Brevibacillus parabrevis (100\%), which is a bacterium that can use organic compounds, such as polycyclic aromatic hydrocarbons, as sole carbon source and is a potential candidate for the biodegradation of low-density polyethylene (Pramila et al., 2012). Band 18, 21, 31, and 34 can only be detected from IO-50. Band 18 and 21were identified as Brevibacillus thermoruber (100\%) and Brevibacillus borstelensis (99\%), respectively. As metabolic products of these thermophilic bacteria, significant amounts of sulfates were generated, which can be precipitated by supplementing the culturing media with ions, leading to insoluble salts (Hadad et al., 2005; Manachini et al., 1985). Band 31 and 34 were closely associated with Bacillus thermophilus (100\%), which is widely distributed in soil, hot springs, and ocean sediments, and is capable of oxidizing carbon monoxide aerobically (Nazina et al., 2001). Band 8 was only found in IO-60, which was related to $\mathrm{Ba}$ cillus sp. (99\%) and usually involved in sulfur odor treatment (Guerrero-Barajas et al., 2011). 
Table 3

The closest relatives and isolation sources of dominate bacteria.

\begin{tabular}{|c|c|c|c|}
\hline Band no. & Closest relatives & Source & Similarity \\
\hline B1, B3 & Pseudomonas stutzeri N2 & $\begin{array}{l}\text { Bacteria; Proteobacteria; Gammaproteobacteria; Pseudomonadales; Pseudomonadaceae; } \\
\text { Pseudomonas. }\end{array}$ & 100 \\
\hline $\begin{array}{l}\text { B2, B4, B5, } \\
\text { B7 }\end{array}$ & Pseudomonas putida D61 & $\begin{array}{l}\text { Bacteria; Proteobacteria; Gammaproteobacteria; Pseudomonadales; } \\
\text { Pseudomonadaceae; Pseudomonas. }\end{array}$ & 100 \\
\hline B6 & Uncultured bacterium B-91 & Bacteria; environmental samples. & 100 \\
\hline B8 & Bacillus sp. G6 & Bacteria; Firmicutes; Bacilli; Bacillales; Bacillaceae; Bacillus. & 99 \\
\hline B9 & Stenotrophomonas acidaminiphila NK4 & $\begin{array}{l}\text { Bacteria; Proteobacteria; Gammaproteobacteria; Xanthomonadales; } \\
\text { Xanthomonadaceae; Stenotrophomonas. }\end{array}$ & 99 \\
\hline $\begin{array}{l}\text { B10, B22, } \\
\text { B25 }\end{array}$ & Geobacillus toebii PW12 & $\begin{array}{l}\text { Bacteria; Firmicutes; Bacilli; Bacillales; Bacillaceae; } \\
\text { Geobacillus. }\end{array}$ & 98 \\
\hline B11, B28 & Uncultured Firmicutes bacterium EJIR08_14 & Bacteria; Firmicutes; environmental samples. & 98 \\
\hline B12, B17 & Anoxybacillus flavithermus 3 & Bacteria; Firmicutes; Bacilli; Bacillales; Bacillaceae; Anoxybacillus. & 100 \\
\hline B13 & Uncultured bacterium SIBN1075 N12D1 16B & Bacteria; environmental samples. & 98 \\
\hline B14 & Brevibacillus sp. КB2 & $\begin{array}{l}\text { Bacteria; Firmicutes; Bacilli; Bacillales; Paenibacillaceae; } \\
\text { Brevibacillus. }\end{array}$ & 99 \\
\hline B15 & Anoxybacillus flavithermus A2 & $\begin{array}{l}\text { Bacteria; Firmicutes; Bacilli; Bacillales; Bacillaceae; } \\
\text { Anoxybacillus. }\end{array}$ & 99 \\
\hline B16 & Uncultured bacterium clone UAFB TA 5216 & Bacteria; environmental samples. & 100 \\
\hline B18 & Brevibacillus thermoruber TS 06 & $\begin{array}{l}\text { Bacteria; Firmicutes; Bacilli; Bacillales; Paenibacillaceae; } \\
\text { Brevibacillus. }\end{array}$ & 100 \\
\hline B19 & Enterobacter sp. SQ6-43-8 & $\begin{array}{l}\text { Bacteria; Proteobacteria; Gammaproteobacteria; Enterobacteriales; } \\
\text { Enterobacteriaceae; Enterobacter. }\end{array}$ & 100 \\
\hline B20 & Brevibacillus parabrevis DMB6 & $\begin{array}{l}\text { Bacteria; Firmicutes; Bacilli; Bacillales; Paenibacillaceae; } \\
\text { Brevibacillus. }\end{array}$ & 100 \\
\hline B21 & Brevibacillus borstelensis $\mathrm{B} 8$ & $\begin{array}{l}\text { Bacteria; Firmicutes; Bacilli; Bacillales; Paenibacillaceae; } \\
\text { Brevibacillus. }\end{array}$ & 99 \\
\hline B23 & Aeribacillus pallidus Billoris-V017 & $\begin{array}{l}\text { Bacteria; Firmicutes; Bacilli; Bacillales; Bacillaceae; } \\
\text { Aeribacillus. }\end{array}$ & 100 \\
\hline B24 & Achromobacter xylosoxidans SR50-12 & $\begin{array}{l}\text { Bacteria; Proteobacteria; Betaproteobacteria; Burkholderiales; } \\
\text { Alcaligenaceae; Achromobacter. }\end{array}$ & 100 \\
\hline B26 & Bacillus thioparans JB3 & Bacteria; Firmicutes; Bacilli; Bacillales; Bacillaceae; Bacillus. & 100 \\
\hline B27, B32 & Microbacterium sp. HGG-15 & $\begin{array}{l}\text { Bacteria; Actinobacteria; Actinobacteridae; Actinomycetales; } \\
\text { Micrococcineae; Microbacteriaceae; Microbacterium. }\end{array}$ & 100 \\
\hline B29, B39 & Uncultured Firmicutes bacterium CM1-134 & Bacteria; Firmicutes; environmental samples. & 100 \\
\hline B30 & Thermoanaerobacteriaceae $91 \mathrm{nM}$ & $\begin{array}{l}\text { Bacteria; Firmicutes; Clostridia; Thermoanaerobacterales; } \\
\text { Thermoanaerobacteraceae; unclassified. }\end{array}$ & 100 \\
\hline B31, B34 & Bacillus thermophilus SgZ-10 & Bacteria; Firmicutes; Bacilli; Bacillales; Bacillaceae; Bacillus. & 100 \\
\hline B33 & Geobacillus debilis D33-8 & Bacteria; Firmicutes; Bacilli; Bacillales; Bacillaceae; Caldibacillus. & 91 \\
\hline B35, B38 & Tuberibacillus calidus 606b & $\begin{array}{l}\text { Bacteria; Firmicutes; Bacilli; Bacillales; Sporolactobacillaceae; } \\
\text { Tuberibacillus. }\end{array}$ & 100 \\
\hline B36 & Lactococcus garvieae FT255 & $\begin{array}{l}\text { Bacteria; Firmicutes; Bacilli; Lactobacillales; Streptococcaceae; } \\
\text { Lactococcus. }\end{array}$ & 100 \\
\hline B37 & $\begin{array}{l}\text { Aneurinibacillus thermoaerophilus Billoris- } \\
\text { VO22 }\end{array}$ & $\begin{array}{l}\text { Bacteria; Firmicutes; Bacilli; Bacillales; Paenibacillaceae; } \\
\text { Aneurinibacillus group; Aneurinibacillus. }\end{array}$ & 100 \\
\hline
\end{tabular}

The percentages of desulfurization and thermophilic bacteria were $36.84 \%$ and $78.95 \%$, respectively. Both bacteria dominated the microbial population in the inocula. The microbial diversity indices of IO-50, IO-55, and IO-60 were 3.41, 3.10, and 3.20, respectively, whereas the amounts of microorganism were approximately $7.49 \times 10^{6}, 1.76 \times 10^{6}$, and $3.04 \times 10^{5} \mathrm{CFU} \mathrm{mL}^{-1}$, respectively. Significant differences were found in the number of bacteria and diversity among IO-50, IO-55, and IO-60. For a bioreactor, the amount and structure of microbial community were greatly correlated with the characteristics of substrates and environment for the survival of bacteria, such as the substrate species and acclimation temperature (Ottengraf, 1986). $\mathrm{SO}_{2}$ was found as the major substrate in the inlet stream. The temperature of the bioreactor where the inocula were collected was $50-60{ }^{\circ} \mathrm{C}$. Therefore, desulfurization and thermophilic bacteria were the main microorganisms in the inocula. Organic matter degradation bacteria can also be detected because of the volatile organic compounds in the air inflow entering the bioreactor. The stream with $\mathrm{SO}_{2}$ entered the bioreactor from the bottom and went through the packing material bed. The stream was then exhausted from the top of the bioreactor. The $\mathrm{SO}_{2}$ concentration declined along the packing material bed. The microorganisms were abundant at the bottom where the substrate was adequate. The temperature changed along with the packing layer, and the microorganisms grew exponentially when the temperature was suitable. However, higher temperature limited microbial growth, resulting in higher microbial diversity of IO-50 than that of IO-55 and IO-60.

In the inocula, Pseudomonas stutzeri (B1, B3), P. putida (B2, B4, B5, B7), Bacillus sp. (B8), Stenotrophomonas acidaminiphila (B9), G. toebii (B10, B22, B25), A. flavithermus (B12, B15, B17), Brevibacillus sp. (B14), B. thermoruber (B18), Enterobacter sp. (B19), B. parabrevis (B20), B. borstelensis (B21), Achromobacter xylosoxidans (B24), Microbacterium sp. (B27, B32), Thermoanaerobacteriaceae (B30), T. calidus (B35, B38), and Lactococcus garvieae (B36) were culturable. Among them, two kinds of bacteria belonging to Pseudomonas notably emerged: P. stutzeri and P. putida. Pseudomonas sp. is usually used to remove sulfur-containing compounds with higher than 90\% removal efficiency (Li et al., 2013; Omri et al., 2011).

\subsubsection{Enrichments}

Lanes DO-50, DO-55, and DO-60 in Fig. 2a represent the bacterial consortium after enrichment for 6 months. The desulfurization bacteria, e.g., Brevibacillus sp. (B14), B. thermoruber (B18), and $B$. borstelensis (B21), and the thermophilic bacteria, including uncultured F. bacterium (B11, B28), B. parabrevis (B20), and Bacillus thermophilus (B31, B34), were found in the microbial communities 


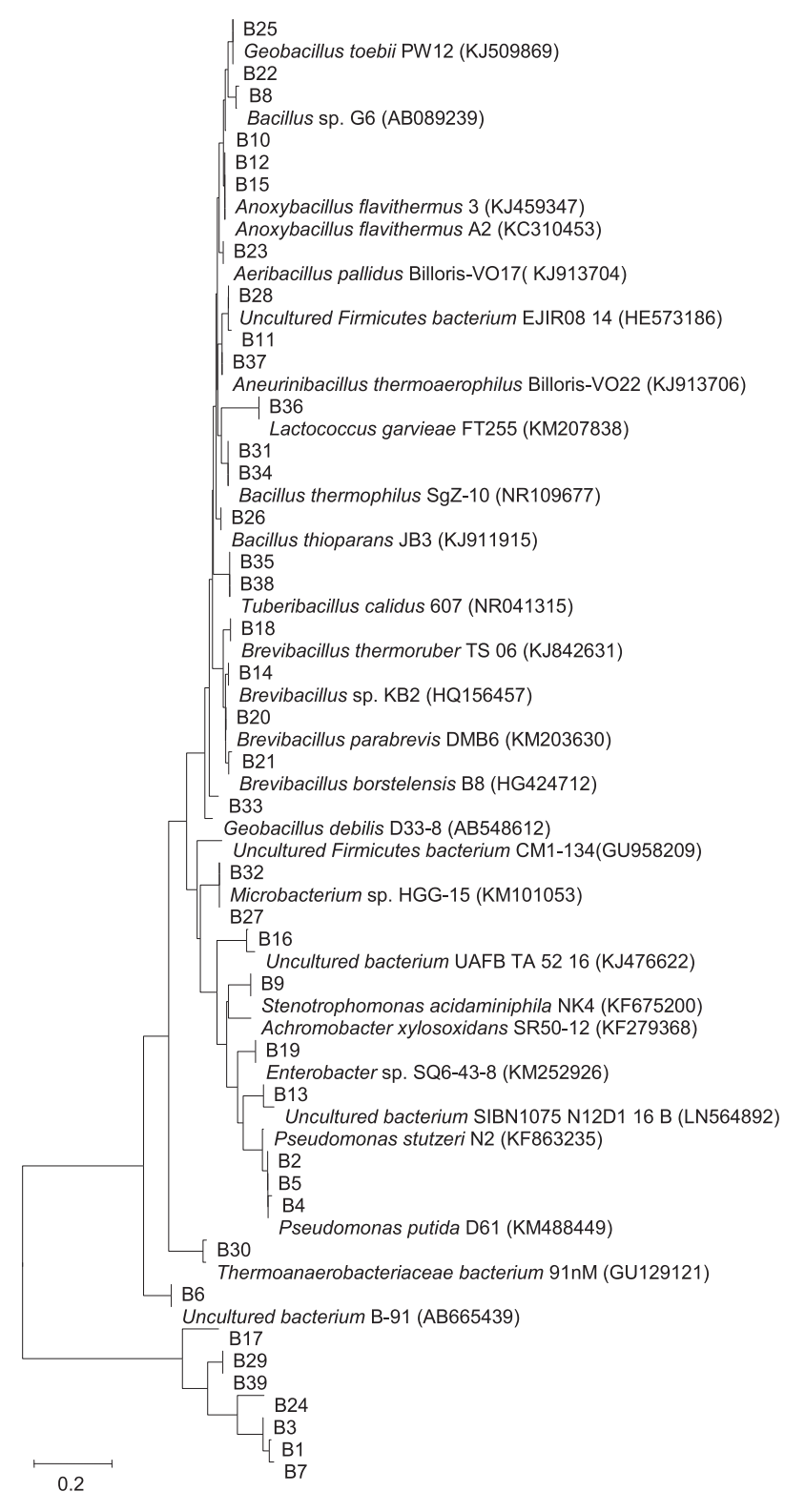

Fig. 3. Phylogenetic tree derived from the neighbor-joining analysis of the partial $16 \mathrm{~S}$ rRNA gene sequence.

of DO-50, DO-55, DO-60. These communities existed in original inocula and were enhanced after enrichment. The amount of these desulfurization and thermophilic bacteria increased after enrichment. Aside from these bacteria, the desulfurization bacteria P. putida (B2, B4, B5, B7), P. stutzeri (B1, B3), and Aneurinibacillus thermoaerophilus (B37) increased when the culture temperature was $50{ }^{\circ} \mathrm{C}$. Meanwhile, $T$. calidus (B35, B39) and Bacillus thioparans (B26) still existed. These bacteria can also be detected when cultured at 55 and $60{ }^{\circ} \mathrm{C}$. In addition, some thermophilic microorganisms, including Bacillus sp. (B8), were enhanced at $55{ }^{\circ} \mathrm{C}$, whereas B10, B22, B25, and B33, which were assigned to two Geobacillus sp., were enhanced at $60{ }^{\circ} \mathrm{C}$. Compared with the consortium cultured at $50{ }^{\circ} \mathrm{C}$, all the enhanced bacteria were thermophilic at 55 and $60{ }^{\circ} \mathrm{C}$ because of the increased temperature.

Lanes DT-50, DT-55, and DT-60 represented the consortium after 12 months of enrichment at 50,55 , and $60{ }^{\circ} \mathrm{C}$, respectively.
When the microorganisms were cultured for 12 months, all the enhanced bacteria were desulfurized and thermophilic bacteria, such as B. thermoruber (B18), B. parabrevis (B20), A. thermoaerophilus (B37), and T. calidus (B35, B39). Meanwhile, some microorganisms were reduced because of their inability to tolerate certain sulfur compound concentrations or to resist high temperatures.

The microbial diversity indices of IO-50, IO-55, and IO-60 were $3.41,3.16$ and 3.20 , respectively, whereas the microbial diversity indices of DO-50, DO-55, and DO-60 were 3.26, 2.97, and 3.15 (Fig. 2a), respectively. Microbial diversity was reduced because some bands were weakened or undetected after enrichment, e.g., B9, which was related to S. acidaminiphila (99\%) and always existed in environments below $40^{\circ} \mathrm{C}$, thereby leading to gradual reduction in diversity during enrichment (Assih et al., 2002). A similar phenomenon occurred in DT-50, DT-55, and DT-60, where microbial diversity was reduced gradually as culture time increased. However, the proportions of desulfurization and thermophilic bacteria after enrichment were $50.00 \%$ and $83.33 \%$, respectively, which increased compared with the inocula. The proportion for enrichment after 12 months increased to $52.94 \%$ and $88.24 \%$, respectively, as the enrichment time grew.

The distribution and relative contents of Pseudomonas sp. and sulfur bacteria in the consortium of microorganisms after acclimation were analyzed by FISH (Fig. 4). Both Pseudomonas sp. (shown in green) and sulfur bacteria (shown in red) exhibited clustered scattering on the consortium with a particle size of $30-80 \mu \mathrm{m}$. The mean frame intensities of the green and red showed that Pseudomonas sp. and sulfur bacteria accounted for a large proportion in the total bacteria. While they did not gather alone, grew together with other bacteria.

\subsection{Genetic evolutionary relationships}

The genetic evolutionary relationships of bacterial communities are presented in Fig. 2b. Inocula (IO-50, IO-55, and IO-60) were associated with the IC series (IC-50, IC-55, and IC-60) because these series were the culturable bacteria in the inocula. Inocula have a distant relationship with the series of DO (DO-50, DO-55, and DO60 ) and DT (DT-50, DT-55, and DT-60). Obvious distinction occurred in the microbial structure after enrichment. The microbial structure depended on the media component, and the bacteria in this study were cultured by sulfur bacteria culture medium. The microbial structure of the DO series was distinguished from that of the DT series because of the different substrates. In addition, the culture condition, e.g., temperature and time, also influenced the microbial structure. As the acclimation time increased, the changes in microbial structure became more evident. DO-50, DO-55, and DO-60 were cultured under different temperatures. Therefore, the individual microbial structures exhibited obvious differences. The microbial population formed in each consortium was closely correlated with the substrate species, acclimation temperature, and acclimation time. Compared with the other factors, substrate had a greater effect in this study.

\subsection{Performance of enrichment-inoculated biofilter}

Thermophilic biofilter had been carried out for 2 months to investigate the biofilter performance. The flow rate and temperature were maintained at $0.6 \mathrm{~m}^{3} \mathrm{~h}^{-1}$ and $60{ }^{\circ} \mathrm{C}$, respectively. The elimination of $\mathrm{SO}_{2}$ which carried out in the biofilter system was an aerobic process. $\mathrm{SO}_{2}$ dissolved in the water and then be oxidized to $\mathrm{SO}_{4}^{2-}$ under aerobic condition (formulas 3 and 4) (Zhang et al., 2015). 

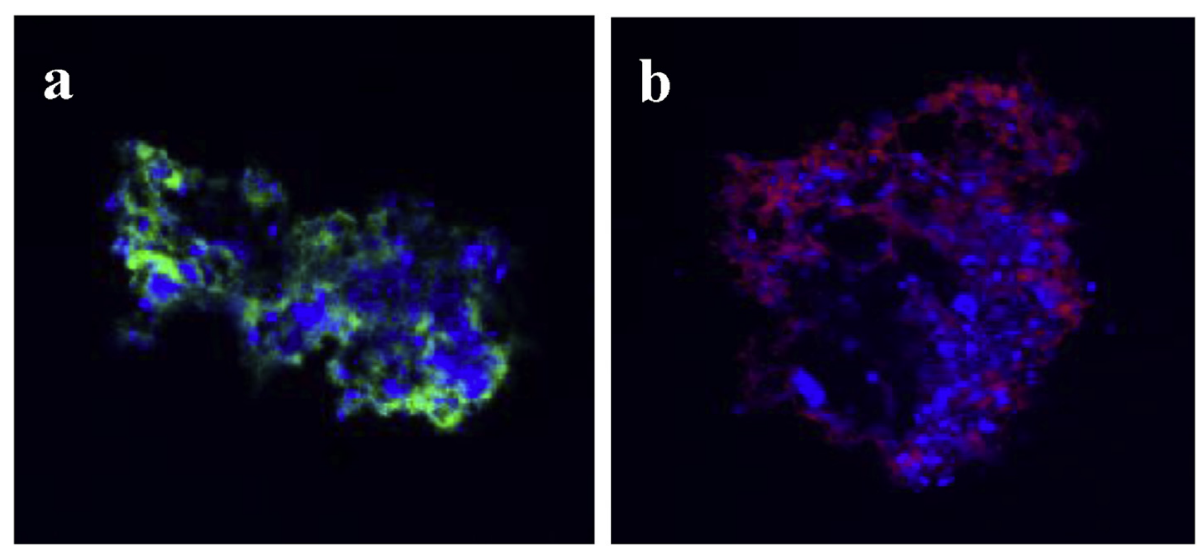

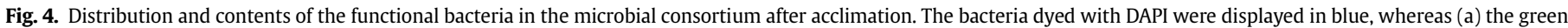

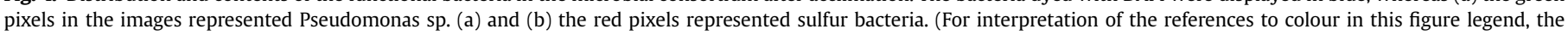
reader is referred to the web version of this article.)

$\mathrm{SO}_{2}+\mathrm{H}_{2} \mathrm{O} \rightarrow \mathrm{SO}_{3}^{2-}+\mathrm{H}^{+}$

$\mathrm{SO}_{3}^{2-}+\mathrm{O}_{2} \rightarrow \mathrm{SO}_{4}^{2-}$

Fig. 5 shows the variation of $\mathrm{SO}_{2}$ concentrations and removal efficiencies. The inlet concentrations of $\mathrm{SO}_{2}$ ranged from $100.0 \mathrm{mg} \mathrm{m}^{-3}$ to $200.0 \mathrm{mg} \mathrm{m}^{-3}$. After 11 days of adaptation, the removal efficiency of $\mathrm{SO}_{2}$ gradually increased from $20 \%$ to more than $80 \%$. Similar to all biosystems, a newly installed biofilter will adapt itself with respect to its microbial ecology and physiological conditions to its environment and nutrient supply of the biofilter before efficient biodegradation occurs (Cox et al., 1993). The startup period of uninoculated biofilters usually takes two weeks to six months. The species in the inocula survive under the environmental conditions of the biofilter (e.g., pH and temperature) and withstand the inevitable variations during the start-up period. Pollutant degradation is a necessary trait for species in a biofilter, and rapid utilization of the pollutant provides the species a competitive advantage (van Groenestijn et al., 1995). In the present study, the microorganisms that can degrade $\mathrm{SO}_{2}$ grew rapidly and proliferated during the acclimation period. Inoculation with desulphurization bacteria hastened acclimation of the thermophilic desulfurization biofilter but did not affect the removal efficiency of the biofilter.

The outlet concentrations in the steady state were from $0 \mathrm{mg} \mathrm{m}^{-3}$ to $50 \mathrm{mg} \mathrm{m}^{-3}$. During 2 months of operating period,

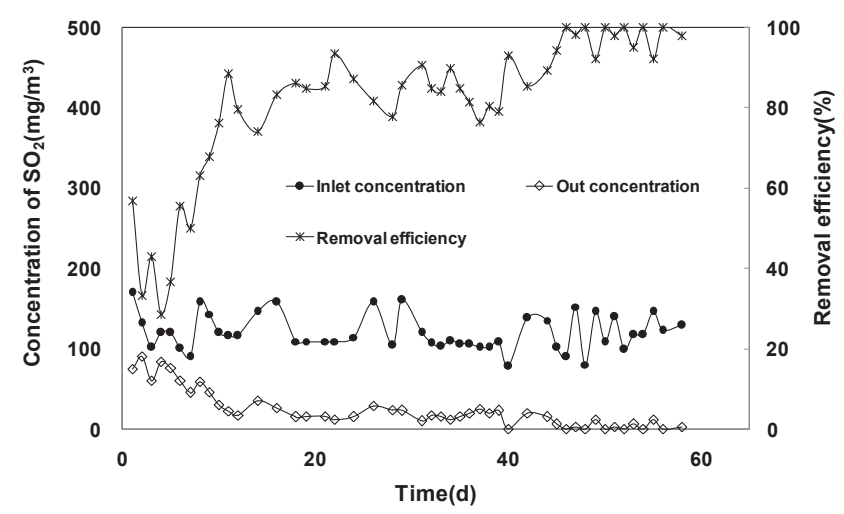

Fig. 5. $\mathrm{SO}_{2}$ concentrations in the bioreactor and removal efficiency. removal efficiency was maintained above $80 \%$. The results showed that the elimination capacity of the thermophilic biofilter increased obviously with the $\mathrm{SO}_{2}$ inlet load (Fig. 6). The biofilter reached the maximum elimination capacity $\left(38.71 \mathrm{~g} \mathrm{~m}^{-3} \mathrm{~h}^{-1}\right)$ at an inlet concentration of $152 \mathrm{mg} \mathrm{m}^{-1}$, and flow rate of $0.6 \mathrm{~m}^{3} \mathrm{~h}^{-1}, \mathrm{SO}_{2}$ at $60{ }^{\circ} \mathrm{C}$ can be effectively removed using the developed thermophilic biofilter. The bioreactor after inoculating enrichment does not only shorten the start-up period but also maintain removal capacity.

\subsection{Microbial population during start-up period}

Lanes T-1 and T-2 in Fig. 2a represent the consortium sampled just after inoculation and 11 days of operation, respectively. The microbial diversity decreased slightly within 11 days of operation. Moreover, 16 bands were found in Lane T-1. The bands were represented by $P$. putida (B7), Bacillus sp. (B8), uncultured $F$. bacterium (B11), A. flavithermus (B12, B15, B17), G. toebii (B22), Bacillus thioparans (B26), Microbacterium sp. (B27, B32), and Bacillus thermophilus SgZ-10(B34). After 11 days, 14 bands existed in Lane T-2. The desulfurization bacteria, e.g., P. putida (B7), Bacillus thioparans (B26), Microbacterium sp. (B27, B32), and Thermoanaerobacteriaceae (B30), were abundant in the biofilter. $\mathrm{SO}_{2}$ was the sole substrate that resulted in the increase in the proportion of sulfur bacteria from $30 \%$ to $40 \%$, whereas some bacteria with the ability to remove

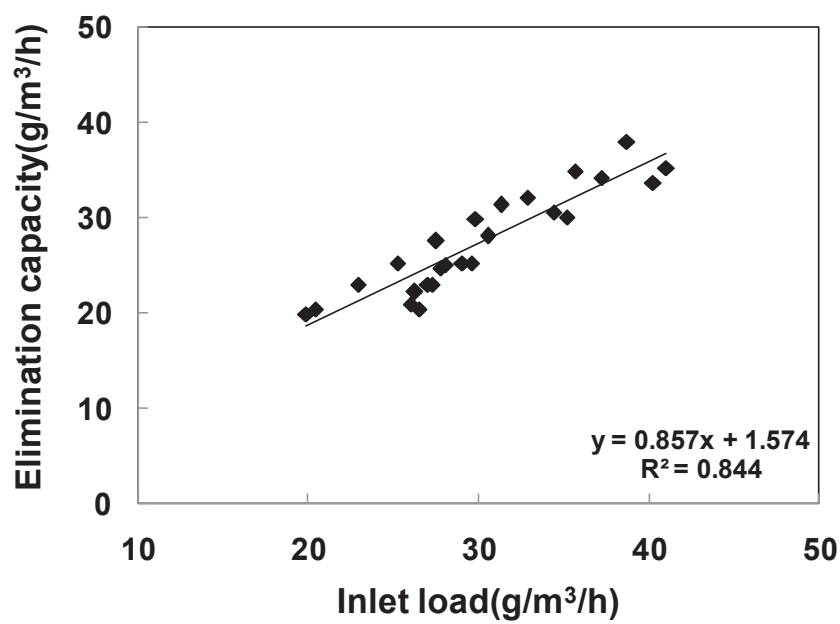

Fig. 6. $\mathrm{SO}_{2}$ elimination capacity VS Inlet load. 
VOC, such as A. flavithermus and Bacillus thermophilus, were lost after 11 days of operation. Given these desulfurization bacteria, $\mathrm{SO}_{2}$ could be treated effectively after the start-up period.

\section{Conclusions}

The microbial population during acclimation and biofilter startup period relied on substrate species and acclimation temperature. The proportion of desulfurization and thermophilic bacteria increased after acclimation. Pseudomonas sp. and sulfur bacteria exhibited clustered scattering in the consortium, with a particle size of $30-80 \mu \mathrm{m}$. The thermophilic biofilter inoculated with enrichments can hasten start-up for $\mathrm{SO}_{2}$ removal. Over $80 \%$ removal efficiency was achieved in the steady state. The desulfurization and thermophilic bacteria P. putida, Bacillus thioparans, and Microbacterium sp. dominated the thermophilic biofilter after the startup period.

\section{Acknowledgments}

The authors express their sincerely acknowledgements to ShineWrite services center of professional editing support for the English revision of the manuscript. The work was financially supported by the Major Science and Technology Program for Water Pollution Control and Treatment (No. 2010ZX07319-001-03) and the National Natural Science Foundation of China (No. 51221892).

\section{References}

Assih, E.A., Ouattara, A.S., Thierry, S., Cayol, J.L., Labat, M., Macarie, H., 2002. Stenotrophomonas acidaminiphila sp. nov., a strictly aerobic bacterium isolated from an upflow anaerobic sludge blanket (UASB) reactor. Int. J. Syst. Evol. Microbiol. $52,559-568$.

Beuger, A.L., Gostomski, P.A., 2009. Development of a biofilter with water content control for research purposes. Chem. Eng. J. 151, 89-96.

Cox, H.H.J., Houtman, J.H.M., Doddema, H.J., Harder, W., 1993. Enrichment of fungi and degradation of styrene in biofilters. Biotechnol. Lett. 15, 737-742.

Devinny, J.S., Deshusses, M.A., Webster, T.S., 1999. Biofiltration for Air Pollution Control. Lewis Publishers, Boca Raton.

Guerrero-Barajas, C., Garibay-Orijel, C., Rosas-Rocha, L., 2011. Sulfate reduction and trichloroethylene biodegradation by a marine microbial community from hydrothermal vents sedi-ments. Int. Biodeterior. Biodegrad. 65, 116-123.

Hadad, D., Geresh, S., Sivan, A., 2005. Biodegradation of polyethylene by the thermophilic bacterium Brevibacillus borstelensis. J. Appl. Microbiol. 98, 1093-1100.

Han, Y.P., Liu, J.X., Guo, X.S., Li, L., 2012. Micro-environment characteristics and microbial communities in activated sludge flocs of different particle size. Bioresour. Technol. 124, 252-258.

Hatayama, K., Shoun, H., Ueda, Y., Nakamura, A., 2006. Tuberibacillus calidus gen. nov., sp. nov., isolated from a compost pile and reclassification of Bacillus naganoensis Tomimura et al. 1990 as Pullulanibacillus naganoensis gen. nov. comb. nov. and Bacillus laevolacticus Andersch et al. 1994 as Sporolactobacillus laevolacticus comb. Nov. Int. J. Syst. Evol. Microbiol. 56, 2545-2551.

Johnson, D.B., Joulian, C., d'Hugues, P., Hallberg, K.B., 2008. Sulfobacillus benefaciens sp. nov., an acidophilic facultative anaerobic Firmicute isolated from mineral bioleaching operations. Extremophiles 12, 789-798.

Kayser, K.J., Cleveland, L., Park, H.S., Kwak, J.H., Kolhatkar, A., Kilbane, J.J., 2002. Isolation and characterization of a moderate thermophile, Mycobacterium phlei GTIS10, capable of dibenzothiophene desulphurization. Appl. Microbiol. Biotechnol. 59, 737-745.

Kim, Y.M., Cho, H.U., Park, K.Y., Park, H., Cho, K.H., 2014. Identification of the bacterial community of a pilot-scale thermophilic aerobic bioreactor treating sewage sludge. Int. Biodeterior. Biodegrad. 92, 66-70.

Leson, G., Smith, B.J., 1997. Petroleum environmental research forum field study on biofilters for control of volatile hydrocarbons. J. Environ. Eng. 123, 556.

Li, L., Liu, J.X., 2006. Removal of xylene from off-gas using a bioreactor containing bacteria and fungi. Int. Biodeterior. Biodegrad. 58, 60-64.

Li, L., Gao, M., Liu, J.X., 2011. Distribution characterization of microbial aerosols emitted from a wastewater treatment plant using the Orbal oxidation ditch process. Process Biochem. 46, 910-915.

Li, L., Han, Y.P., Yan, X., Liu, J.X., 2013. $\mathrm{H}_{2} \mathrm{~S}$ removal and bacterial structure along a full-scale biofilter bed packed with polyurethane foam in a landfill site. Bioresour. Technol. 147, 52-58.

Lin, J., Li, L., Ding, W.J., Zhang, J.Y., Liu, J.X., 2015. Continuous desulfurization and bacterial community structure of an integrated bioreactor developed to treat $\mathrm{SO}_{2}$ from a gas stream. J. Environ. Sci. 37, 130-138.

Manachini, P.L., Fortina, M.G., Parini, C., Craveri, R., 1985. Bacillus thermoruber sp. Nov., nom. rev., a red-pigmented thermophilic bacterium. Int. J. Syst. Bacteriol. 35, 493-496.

Mnif, S., Sayadi, S., Chamkha, M., 2014. Biodegradative potential and characterization of a novel aromatic-degrading bacterium isolated from a geothermal oil field under saline and thermophilic conditions. Int. Biodeterior. Biodegrad. 86 $258-264$.

Nazina, T.N., Tourova, T.P., Poltaraus, A.B., Novikova, E.V., Grigoryan, A.A. Ivanova, A.E., Lysenko, A.M., Petrunyaka, V.V., Osipov, G.A., Belyaev, S.S. Ivanov, M.V., 2001. Taxonomic study of aerobic thermophilic bacilli: descriptions of Geobacillus subterraneus gen. nov., sp. nov. and Geobacillus uzenensis sp. nov. from petroleum reservoirs and transfer of Bacillus stearothermophilus, Bacillus thermocatenulatus, Bacillus thermoleovorans, Bacillus kaustophilus, Bacillus thermoglucosidasius and Bacillus thermodenitrificans to Geobacillus as the new combinations. Int. J. Syst. Evol. Microbiol. 51, 433-446.

Omri, I., Bouallagui, H., Aouidi, F., Godon, J.J., Hamdi, M., 2011. $\mathrm{H}_{2} \mathrm{~S}$ gas biological removal efficiency and bacterial community diversity in biofilter treating wastewater odor. Bioresour. Technol. 102, 10202-10209.

Ottengraf, S.P.P., 1986. Exhaust gas purification. In: Rehm, H.-J., Reeds, G. (Eds.), BiotechnologyVCH Verlagsgelsellshaft, Weinheim, pp. 426-452, 8.

Ozdemir, S., Bekler, F.M., Okumus, V., Dundar, A., Kilinc, E., 2012. Biosorption of 2,4D, 2,4-DP, and 2,4-DB from aqueous solution by using thermophilic Anoxybacillus flavithermus and analysis by high-performance thin layer chromatography: equilibrium and kinetic studies. Environ. Prog. Sustain. 31, 544-552.

Pérez-Ibarra, B.M., Flores, M.E., García-Varela, M., 2007. Isolation and characterization of Bacillus thioparus sp. nov., chemolithoautotrophic, thiosulfateoxidizing bacterium. FEMS Microbiol. Lett. 271, 289-296.

Philip, L., Deshusses, M.A., 2003. Sulfur dioxide treatment from flue gases using a biotrickling filter-bioreactor system. Environ. Sci. Technol. 37, 1978-1982.

Pramila, R., Padmavathy, K., Vijaya, R.K., Mahalakshmi, K., 2012. Brevibacillus parabrevis, Acinetobacter baumannii and Pseudomonas citronellolis - potential candidates for biodegradation of low density polyethylene (LDPE). J. Bacteriol. Res. 4, 9-14.

Ralebitso-Senior, T.K., Senior, E., Di Felice, R., Jarvis, K., 2012. Waste gas biofiltration: advances and limitations of current approaches in microbiology. Environ. Sci. Technol. 46, 8542-8573.

Saake, M., Hübner, R., 1989. In: Einsatz von Biofiltern zur Behandlung lösemittelhaltiger Abluft, Seminar "Biologische Abgasreinigung", 23/24.

Saha, R., Donofrio, R.S., Goeres, D.M., Bagley, S.T., 2012. Rapid detection of rRNA group I pseudomonads in contaminated metalworking fluids and biofilm formation by fluorescent in situ hybridization. Appl. Microbiol. Biotechnol. 94, 799-808.

Sakuma, T., Jinsiriwanit, S., Hattori, T., Deshusses, M.A., 2008. Removal of ammonia from contaminated air in a biotrickling filter-denitrifying bioreactor combination system. Water Res. 42, 4507-4513.

Shang, S.M., Oian, L., Zhang, X. Li, K.Z, 2013. Themoanaerobacterium calidifontis sp. Nov., a novel anaerobic, thermophilic, ethanolproducing bacterium from hot springs in China. Arch. Microbiol. 195, 439-445.

Shareefdeen, Z., Singh, A., 2005. Biotechnology for Odor and Air Pollution Control Springer, Berlin.

Shu, C.C.H., Chen, C.K., 2009. Enhanced removal of dimethyl sulfide from a synthetic waste gas stream using a bioreactor inoculated with Microbacterium sp. NTUT26 and Pseudomonas putida. J. Ind. Microbiol. Biotechnol. 36, 95-104.

Thompson, J.D., Gibson, T.J., Plewniak, F., Jeanmougin, F., Higgins, D.G., 1997. The Clustal X windows interface: flexible strategies for multiple sequence alignment aided by quality analysis tools. Nucleic Acids Res. 24, 4876-4882.

Ueno, Y., Tatara, M., 2008. Microbial population in a thermophilic packed-bed reactor for methanogenesis from volatile fatty acids. Enzyme Microb. Technol. 43, 302-308.

van Groenestijn, J.W., Hesselink, P.G.M., 1993. Biotechniques for air pollution control. Biodegradation 4, 283-301.

van Groenestijn, J.W., Harkes, M., Cox, H., Doddema, H., 1995. Geramic materials in biofiltration. In: Hodge, D.S., Reynolds, F.E. (Eds.), Proceedings of the 1995 Conference on Biofiltration (An Air Pollution Control Technology). The Reynolds Group, Tustin, CA.

Wright, W.F., Schroeder, E.D., Chang, D.P.Y., Romstad, K., 1997. Performance of a pilot-scale compost bilfilter treating gasoline vapor. J. Environ. Eng. 123, 547.

Xue, N.T., Wang, Q.H., Wang, J., Wang, J.H., Sun, X.H., 2013. Odorous composting gas abatement and microbial community diversity in a biotrickling filter. Int. Biodeterior. Biodegrad. 82, 73-80.

Yasawong, M., Areekit, S., Pakpitchareon, A., Santiwatanakul, S., Chansiri, K., 2011. Characterization of thermophilic halotolerant Aeribacillus pallidus TD1 from Tao Dam hot spring. Thail. Int. J. Mol. Sci. 12, 5294-5303.

Zhang, J.Y., Li, L., Liu, J.X., 2015. Thermophilic biofilter for $\mathrm{SO}_{2}$ removal: performance and microbial characteristics. Bioresour. Technol. 180, 106-111.

Zhao, Y.G., Wang, A.J., Wan, C.L., Ren, N.Q., Bai, J., 2009. Design and assessment of species-specific primer and probe for Thiobacillus denitrificans. Microbiology 36, 652-657 (In Chinese). 